\title{
Ethanol Extract of Detam 1 Soybean Seed (Glycine Max L. Merr) for Chronic Kidney Disease Therapy by In Vitro Study
}

\author{
Sijani Prahastuti ${ }^{1}$, Meilinah Hidayat ${ }^{1}$, Stella Tinia Hasiana1, Wahyu Widowati ${ }^{*}$, Annisa Amalia ${ }^{2}$, \\ Rismawati Laila Qodariah², Rizal Rizal2,3, Satrio Haryo Benowo Wibowo², Hanna Sari Widya \\ Kusuma ${ }^{2}$ \\ ${ }^{1}$ Faculty of Medicine, Maranatha Christian University, \\ ${ }^{2}$ Aretha Medika Utama, Biomolecular and Biomedical Research Center, \\ ${ }^{3}$ Biomedical Engineering, Department of Electrical Engineering, Faculty of Engineering, Universitas Indonesia,
}

\begin{abstract}
Chronic Kidney Disease (CKD) has increased incidence and prevalence in developing nations. In this in vitro study, we evaluated the cells proliferative effects, fibronectin (FN), transforming growth factor $\beta$ (TGF- $\beta 1$ ), and Reactive oxygen species (ROS) - level inhibition potential of ethanol extract of detam 1 soybean seed (EEDS) on glucose-induced kidney mesangial cells (SV40 MES 13). The cells proliferation assay used 3-(4,5-dimethylthiazol-2-yl)-5-(3-carboxymethoxyphenyl)-2-(4-sulfophenyl)2H-tetrazolium (MTS) assay. FN and TGF- $\beta 1$ level were measured using ELISA assay kit and ROS level using flow cytometry. Level of FN, TGF- $\beta 1$ and ROS, on CKD cells model ( $5 \mathrm{mM}, 10 \mathrm{mM}$ glucose-induced mesangial cell) treated with EEDS $6.25 \mu \mathrm{g} / \mathrm{mL}$ were lower significantly compared to positive control, EEDS improve cells viability and decrease FN, TGF- $\beta 1$ and ROS level in glucose-induced kidney mesangial cells as CKD cells model.
\end{abstract}

Keywords: chronic kidney disease; fibronectin; ROS; soybean; TGF- $\beta 1$

\section{INTRODUCTION}

Chronic Kidney Disease (CKD) is a condition when a renal injury occurs, resulting ina decreased of renal excretory function, thus causing an accumulation of waste and metabollic products. These products accumulations in blood and organs will cause various complications. CKD presents a therapeutic challenge because of the high prevalence and high cost of dialysis. CKD can be caused by various factors such as hypertension, diabetes, infection, atherosclerosis, and others. CKD also becomes a risk factor of cardiovascular disease. Patients with CKD are restricted to protein intake as it will prevent complication and alleviate uremic symptoms in CKD (Garci'a-Sa'nchez et al., 2010; Ranich and Velasquez, 2001).

The filtration unit of the kidney is the glomerulus, a capillary network supported by mesangial cells and extracellular matrix (ECM). Increased levels of the ECM protein fibronectin (FN) are also present; however, its role in diabetic nephropathy (DN) is unknown. Kidney mesangial cells cultured under high glucose conditions provide a model system for studying the effect high glucose on FN and collagen IV (COL4) (Miller et al., 2014), transforming growth factor- $\beta$ (TGF- $\beta$ ) deposition (Widowati et al., 2018; Prahastuti et al., 2019a).

\footnotetext{
*Corresponding author: Wahyu Widowati

Email : wahyu_w60@yahoo.com
}

ECM accumulation by enhancing mesangial cell production of COL and FN. TGF- $\beta$ mediated FN expression in mesangial cells (Uchiyama-Tanaka et al., 2002). Reactive Oxygen Species (ROS) also underlies as a common pathogenic component and accelerates the kidney disease progression and complications (Dounousi et al., 2006; Widowati et al., 2018; Prahastuti et al., 2019a). Soybean seed showed an antioxidant effect and an antifibrotic effect in the remnant kidney, which resulted in the improvement of the renal function. Oxidative stress is regulated by the balance between prooxidant and antioxidant systems (Peng et al., 2017; Hayata et al., 2012; Prahastuti et al., 2019b). Soybean seed (Glycine max L. Merr) has been known for its beneficial effects in health due to its compounds. Previous studies reported that soybean contains antinutritional factors (ANF) which include lipase inhibitors, protease inhibitors, amylase inhibitors, oxalic acid, phytic acid, glucosinolates, flavonoid, and saponin. The ethanol extract of soybean also known to contain natural compounds such as flavonoid, phenolic, triterpenoid, saponin, steroid, tannin, and quinon (Gemede and Ratta, 2014; Prahastuti et al., 2019b). In this study, we evaluated the potency of Glycine $\max$ L. Merr ethanol extract (EEDS) for CKD therapy by measuring the cells proliferation effect, FN, TGF- $\beta 1$, and ROS level on glucose-induced kidney mesangial cells (SV40 MES 13). 


\section{METHODOLOGY \\ Plants Extract Preparation}

Glycine max L. (soybeans) varieties of detam 1 was collected from Unit Pengelolaan Benih Sumber (UPBS) Balai Penelitian Tanaman Aneka Kacang dan Umbi, Malang, East Java, Indonesia. The plants were identified by herbarium staff, Department of Biology, School of Life Science and Technology, Bandung Institute of Technology, Bandung, West Java, Indonesia. Soybeans seed were kept in drier tunnel service and the dried soybean then grinded, mashed into powder. Extraction using 70\% distilled ethanol and performed based on maceration method (Widowati et al., 2016; Widowati et al., 2017; Widowati et al., 2018; Hidayat et al., 2016; Prahastuti et al., 2019b).

\section{Glucose-induced Mesangial Cells for Viability Assay}

The mesangial cells (kidney/glomerulus of Mus musculus) (SV40 MES 13 (ATCC $®$ CRL-1927 ${ }^{\mathrm{TM}}$ ) was obtained from Aretha Medika Utama, Bimolecular and Biomedical Research Center, Bandung, West Java, Indonesia. The cells $5 \times 10^{3}$ cells/well were platted in 96-well plate in $200 \mu \mathrm{L}$ growth medium (DMEM) (Gibco, 11995065): F12$\mathrm{K}$ Mix Nutrient (Gibco, 21127022) (with comparison $1: 3$ ), $5 \%$ of fetal bovine serum (FBS) (Gibco, 10270106), 1\% of Antibiotic-Antimycotic (Gibco, 1772653), $0.1 \%$ Gentamicin (Gibco, 15750060 ) and incubated at $37^{\circ} \mathrm{C}, 5 \% \mathrm{CO}_{2}$ for 24 h. Medium were discarded and added $180 \mu \mathrm{L}$ of $(5$ $\mathrm{mM}, 25 \mathrm{mM}$ and $125 \mathrm{mM})$ glucose-induced medium and $20 \mu \mathrm{l}$ of EEDS $(6.25 \mu \mathrm{g} / \mathrm{ml}$ and 3.125 $\mu \mathrm{g} / \mathrm{mL})$. Cells were incubated at $37^{\circ} \mathrm{C}, 5 \% \mathrm{CO}_{2}$ for 5, 10 and 15 days. Viability were measured at day 5, 10 dan 15 using MTS (3-(4,5-dimethylthiazol-2yl)-5-(3-carboxymethoxyphenyl)-2-(4 sulfophenyl )-2H-tetrazolium) Assay Kit (Abcam, ab197010). The absorbance at $490 \mathrm{~nm}$ using Multiskan GO plate reader (Thermo Scientific, 1510) for calculating the percentage of cell - viability (Widowati et al., 2018; Prahastuti et al., 2019a).

\section{Quantification of TGF- $\beta 1$ Level}

The quantitative determination of TGF- $\beta 1$ level in the cell-free supernatant was performed using mouse TGF- $\beta 1$ ELISA Kit (Elabscience, E-ELM0051) based on manufactured protocol. Concisely, $100 \mu \mathrm{L}$ of standard, sample and blank solution was added into each well then incubated 90 minutes at $37^{\circ} \mathrm{C}$. The cell-free supernatant after treated with EEDS were served as the sample. The glucose-induced mesangial cell free supernatant without extract was used as positive control. The normal cell or untreated cell was used as negative control. Afterward, the liquid of each well was discarded and $100 \mu \mathrm{L}$ Biotinylated Detection $\mathrm{Ab}$ was added then incubated for an hour at $37^{\circ} \mathrm{C}$. Then the liquid was dumped and the plate was washed three times using $200 \mu \mathrm{L}$ wash buffer. 100 $\mu \mathrm{L}$ HRP Conjugate was added and incubated for 30 minutes at $37^{\circ} \mathrm{C}$. The liquid was dumped again and the plate was washed five times using $200 \mu \mathrm{L}$ wash buffer. $90 \mu \mathrm{L}$ Substrate Reagent was added and incubated for 15 minutes at $37^{\circ} \mathrm{C}$. $50 \mu \mathrm{L}$ Stop Solution was added and the absorbance was read at $450 \mathrm{~nm}$ (Widowati et al., 2018; Dai et al., 2014; Prahastuti et al., 2019a).

\section{Quantification of Fibronectin Level}

The quantitative determination of Fibronectin level in the cell-free supernatant was performed using mouse FN ELISA Kit (ElabScience, E-EL-M0506) based on manufactured protocol. Concisely, $100 \mu \mathrm{L}$ of sample, standard, and blank solution was added into each well then sealed and incubated for 90 minutes at $37^{\circ} \mathrm{C}$. The cell-free supernatant, after glucose induced mesangial cells and treated with EEDS was served as the sample. The glucose-induced mesangial cell free supernatant without extract was used as positive control. The untreated cell or normal cell was used as negative control. Afterward, the liquid of each well was discarded and $100 \mu \mathrm{L}$ of Biotinylated Detection $\mathrm{Ab}$ was added then incubated for an hour at $37^{\circ} \mathrm{C}$. Then the liquid was dumped and the plate was washed three times using $200 \mu \mathrm{L}$ wash buffer. $100 \mu \mathrm{L}$ HRP Conjugate was added and incubated for 30 minutes at $37^{\circ} \mathrm{C}$. The liquid was dumped again and the plate was washed five times using $200 \mu \mathrm{L}$ wash buffer. $90 \mu \mathrm{L}$ Substrate Reagent was added and incubated for 15 minutes at $37^{\circ} \mathrm{C} .50 \mu \mathrm{L}$ Stop Solution was added and the absorbance was read at $450 \mathrm{~nm}$ (Widowati et al., 2018; Dai et al., 2014; Pankov et al., 2004; Prahastuti et al., 2019a).

\section{Quantification of Reactive Oxygen Species}

The ROS generation of SV40 MES 13 cells induced with glucose were measured using the DCFDA - Cellular Reactive Oxygen Species Detection Assay Kit (Abcam, ab113851,) and flow cytometry. SV40 MES13 cells were suspended into buffer DCFDA in FACS tube at final concentration of 250,000 cells per $500 \mu \mathrm{L}$. DCFDA was added to cells suspension at final concentration $20 \mu \mathrm{M}$ on each tube. The cells was then incubated at $37^{\circ} \mathrm{C}, 5 \% \mathrm{CO}_{2}$ (dark room) for 45 minutes. Glucose $5 \mathrm{mM}$ and $10 \mathrm{mM}$ (Amresco, 0188) and EEDS $(6.25 \mu \mathrm{g} / \mathrm{mL}$ and $3.125 \mu \mathrm{g} / \mathrm{mL}$ ) were added to each tube. The TBHPinduced mesangial cell free supernatant without extract was used as positive control. The normal cell or untreated cell was used as 
Table I. Effect of EEDS towards viability of glucose-induced kidney mesangial cells at 5 days of incubation

\begin{tabular}{lcccc}
\hline \multirow{2}{*}{ Sample } & \multicolumn{4}{c}{ Glucose Concentration } \\
\cline { 2 - 5 } & $\mathbf{0 ~ M m}$ & $\mathbf{5 ~ m M}$ & $\mathbf{2 5} \mathbf{~ m M}$ & $\mathbf{1 2 5} \mathbf{~ m M}$ \\
\hline Control & $100.00 \pm 5.84 \%^{\mathrm{a}}$ & $100.00 \pm 5.84 \%^{\mathrm{a}}$ & $100.00 \pm 5.84 \%^{\mathrm{a}}$ & $100.00 \pm 5.84 \%^{\mathrm{cd}}$ \\
Positive Control & & $96.71 \pm 0.91 \%^{\mathrm{a}}$ & $84.78 \pm 1.71 \%^{\mathrm{a}}$ & $74.92 \pm 1.30 \%^{\mathrm{a}}$ \\
EEDS 3.125 $\mathrm{\mu g} / \mathrm{mL}$ & $176.85 \pm 28.81 \%^{\mathrm{c}}$ & $193.66 \pm 29.67 \%^{\mathrm{c}}$ & $142.59 \pm 21.84 \%^{\mathrm{b}}$ & $99.03 \pm 2.03 \%^{\mathrm{c}}$ \\
EEDS $6.25 \mu \mathrm{g} / \mathrm{mL}$ & $147.34 \pm 16.30 \%^{\mathrm{b}}$ & $163.42 \pm 24.59 \%^{\mathrm{b}}$ & $158.42 \pm 9.80 \%^{\mathrm{c}}$ & $95.16 \pm 3.85 \%^{\mathrm{b}}$ \\
\hline
\end{tabular}

*Data is served in average \pm standard deviation. Different superscript letters in the same column of $0 \mathrm{mM}$ $(a, b, c), 5 \mathrm{mM}(\mathrm{a}, \mathrm{b}, \mathrm{c}), 25 \mathrm{mM}(\mathrm{a}, \mathrm{b}, \mathrm{c}), 125 \mathrm{mM}$ (a,b,c,cd,) glucose concentration show significant differences among treatments of EEDS concentrations $(P<0.05)$ analyzed using ANOVA and Duncan post hoc test.

Table II. Effect of EEDS towards viability of glucose-induced kidney mesangial cells at 10 days of incubation

\begin{tabular}{lcccc}
\hline \multirow{2}{*}{ Concentration } & \multicolumn{4}{c}{ Glucose Concentration } \\
\cline { 2 - 5 } & $\mathbf{0 ~ m M}$ & $\mathbf{5 ~ m M}$ & $\mathbf{2 5} \mathbf{~ m M}$ & $\mathbf{1 2 5} \mathbf{~ m M}$ \\
\hline Control & $100.00 \pm 5.84^{\mathrm{a}}$ & $100.00 \pm 5.84^{\mathrm{a}}$ & $100.00 \pm 5.84^{\mathrm{bc}}$ & $100.00 \pm 5.84^{\mathrm{c}}$ \\
Positive Control & & $96.64 \pm 0.43^{\mathrm{a}}$ & $86.84 \pm 1.50^{\mathrm{a}}$ & $73.26 \pm 2.25^{\mathrm{a}}$ \\
EEDS 3.125 $\mu \mathrm{g} / \mathrm{mL}$ & $147.24 \pm 15.42^{\mathrm{b}}$ & $111.10 \pm 4.43^{\mathrm{ab}}$ & $99.63 \pm 0.49^{\mathrm{b}}$ & $88.70 \pm 0.66^{\mathrm{b}}$ \\
EEDS $6.25 \mu \mathrm{g} / \mathrm{mL}$ & $110.11 \pm 1.87^{\mathrm{ab}}$ & $133.98 \pm 21.57^{\mathrm{b}}$ & $99.07 \pm 1.62^{\mathrm{b}}$ & $99.08 \pm 1.32^{\mathrm{c}}$ \\
\hline
\end{tabular}

${ }^{*}$ Data is served in average \pm standard deviation. Different superscript letters in the same column of $0 \mathrm{mM}$ (a,ab,), $5 \mathrm{mM}(\mathrm{a}, \mathrm{ab}, \mathrm{b}), 25 \mathrm{mM}$ (a,b,bc), $125 \mathrm{mM}$ (a,b,c,) glucose concentration show significant differences among treatments of EEDS concentrations $(P<0.05)$ analyzed using ANOVA and Duncan post hoc test.

Table III. Effect of EEDS towards kidney mesangial cells viability in glucose-induced mesangial cells at 15 days of incubation

\begin{tabular}{lcccc}
\hline \multirow{2}{*}{ Concentration } & \multicolumn{4}{c}{ Glucose Concentration } \\
\cline { 2 - 5 } & $\mathbf{0 ~} \mathbf{~ m M}$ & $\mathbf{5 ~ m M}$ & $\mathbf{2 5} \mathbf{~ m M}$ & $\mathbf{1 2 5} \mathbf{~ m M}$ \\
\hline Control & $100.00 \pm 5.84^{\mathrm{a}}$ & $100.00 \pm 5.84^{\mathrm{b}}$ & $100.00 \pm 5.84^{\mathrm{d}}$ & $100.00 \pm 5.84^{\mathrm{d}}$ \\
Positive Control & & $76.89 \pm 2.13^{\mathrm{a}}$ & $70.94 \pm 1.80^{\mathrm{a}}$ & $54.12 \pm 4.18^{\mathrm{a}}$ \\
EEDS $3.125 \mu \mathrm{g} / \mathrm{mL}$ & $110.44 \pm 11.69^{\mathrm{b}}$ & $102.72 \pm 16.21^{\mathrm{b}}$ & $91.44 \pm 7.35^{\mathrm{c}}$ & $67.77 \pm 12.59^{\mathrm{c}}$ \\
EEDS $6.25 \mu \mathrm{g} / \mathrm{mL}$ & $117.40 \pm 8.35^{\mathrm{bc}}$ & $100.62 \pm 9.04^{\mathrm{b}}$ & $82.59 \pm 3.86^{\mathrm{b}}$ & $63.61 \pm 6.77^{\mathrm{b}}$ \\
\hline
\end{tabular}

*Data is served in average \pm standard deviation. Different superscript letters in the same column of $0 \mathrm{mM}$ (a,b,bc) $, 5 \mathrm{mM}(\mathrm{a}, \mathrm{b}), 25 \mathrm{mM}(\mathrm{a}, \mathrm{b}, \mathrm{c}, \mathrm{d}), 125 \mathrm{mM}$ (a,b,c,d ) glucose concentration show significant differences among treatments of EEDS concentrations $(P<0.05)$ analyzed using ANOVA and Duncan post hoc test.

negative control. Cells were incubated at $37^{\circ} \mathrm{C}, 5 \%$ $\mathrm{CO}_{2}$ (dark room) for 4 hours. ROS was measured by flow cytometer (Gilmore et al., 2017; Prahastuti et al., 2019a).

\section{Effect EEDS toward Kidney Mesangial Cells Viability \\ Statistical Analysis}

SPSS 16 (SPSS Inc., Chicago, IL, USA) was used for analyzing data to perform one-way ANOVA to verify the results of different treatments and Duncan post hoc and T-Test was used to validate significant differences for all treatments $(\mathrm{p}<0.05)$. The results are displayed as means \pm standard deviation.

\section{RESULT AND DISCUSSION}

Excessive amount of glucose in renal leads to an activation of many metabolic pathways which further leads to an increase of ROS (Yu et al., 2011).
These activated pathways induce release of ECM components such as FN and TGF- $\beta 1$. These increase of and TGF- $\beta 1$ are closely linked to glomerulosclerosis which further lead to CKD (Loeffler and Wolf, 2013; Widowati et al., 2018; Prahastuti et al., 2019a).

The viability of glucose-induced SV 40 MES 13 and treated with EEDS were assessed for 5, 10, and 15 days of incubation. The results were shown in Table I, II, and III. Based on the result, the viability of EEDS $3.125 \mu \mathrm{g} / \mathrm{mL}$ and $6.25 \mu \mathrm{g} / \mathrm{mL}$ are significantly higher than positive control at some levels of glucose-induced and days of incubation. However, the viability of samples at day 15 of incubation showed lower viability compared to other incubation time. The viability of each sample is decreased when the incubation time is longer. This result was in line with previous research that jati belanda leaf and mangosteen peel extracts improved cell viability on glucose-induced mouse 


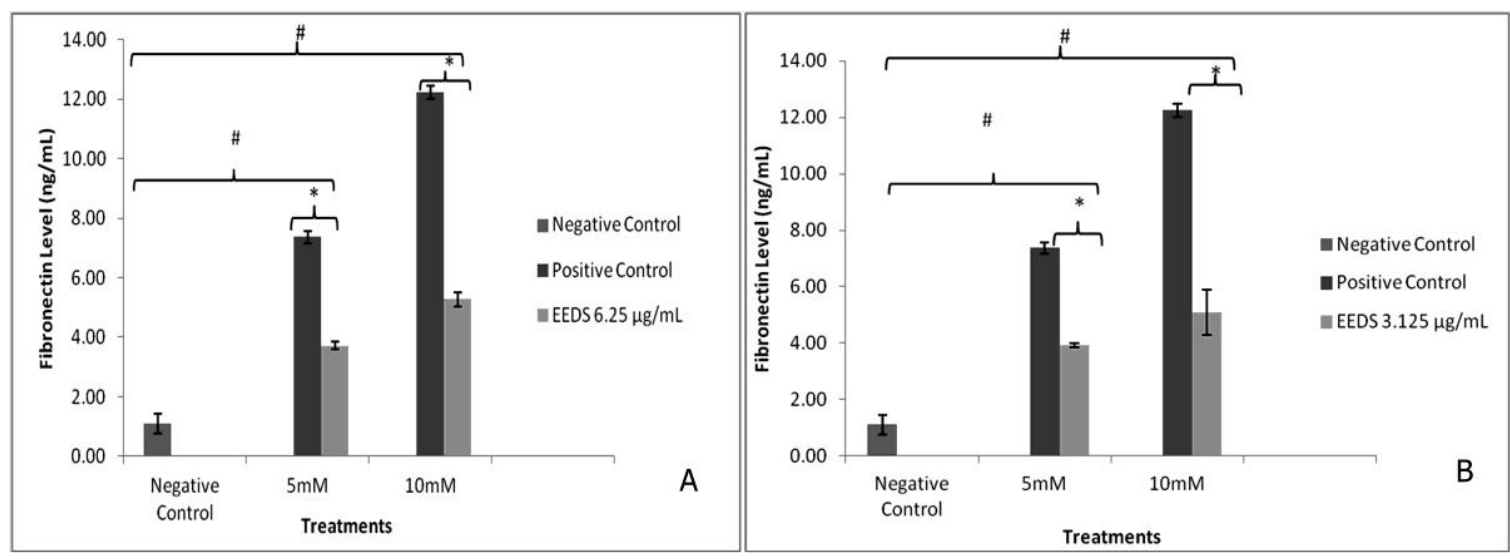

Figure 1. Effect EEDS (3.125 $\mu \mathrm{g} / \mathrm{mL}, 6.25 \mu \mathrm{g} / \mathrm{mL})$ toward FN level on $5 \mathrm{mM}$ and $10 \mathrm{mM}$ glucose-induced kidney mesangial cells

*The histogram are presented as mean \pm standard deviation of negative control, positive control and EEDS $6.25 \mu \mathrm{g} / \mathrm{mL}(\mathrm{A})$ and EEDS $3.125 \mu \mathrm{g} / \mathrm{mL}(\mathrm{B})$. Asterisk symbols $\left({ }^{*}\right)$ show significant difference between positive control ( $5 \mathrm{mM}, 10 \mathrm{mM}$ glucose induction) and EEDS $6.25 \mu \mathrm{g} / \mathrm{mL}$ treatment, between positive control ( $5 \mathrm{mM}, 10 \mathrm{mM}$ glucose induction) and $3.125 \mu \mathrm{g} / \mathrm{mL}$ treatment on cells $(P<0.05)$ (independent $T$-test). Pound symbol (\#) show significant difference between negative control and positive control ( $5 \mathrm{mM}$ glucose induction), negative control and positive control $(10 \mathrm{mM}$ glucose induction) $(P<0.05)$ (independent $T$-test).

kidney cells (Widowati et al., 2018; Prahastuti et al., 2019a)

At 5 days of incubation, the viability of $5 \mathrm{mM}$ glucose-induced EEDS $3.125 \mu \mathrm{g} / \mathrm{mL}$ was the highest among other samples (193.66 $\pm 29.67 \%)$ while EEDS at concentration $6.25 \mu \mathrm{g} / \mathrm{mL}$ was lower compared to EEDS $3.125 \mu \mathrm{g} / \mathrm{mL}$ $(163.42 \pm 24.59 \%)$ (Table I). Both treatments of EEDS (3.125; $6.25 \mu \mathrm{g} / \mathrm{mL})$ were significantly different compared to positive control. At 10 days incubation, EEDS $6.25 \mu \mathrm{g} / \mathrm{mL}$ with $5 \mathrm{mM}$ glucoseinduced had the highest viability $(133.98 \pm 21.57 \%)$ compared to other treatments then the viability gradually decrease, EEDS $3.125 \mu \mathrm{g} / \mathrm{mL}$ also shows the same pattern (Table II). However, a higher level of glucose induction decreased mesangial cell viability. This pattern is also shown at 10 days incubation, the highest viability was EEDS 6.25 $\mu \mathrm{g} / \mathrm{mL}$ at $5 \mathrm{mM}$ glucose induction $(133.98 \pm 21.57 \%)$. The highest cell viability $(100.62 \pm 9.04 \%)$ was 15 days incubation (Table III), on $5 \mathrm{mM}$ glucose-induced cells and treated with EEDS $3.125 \mu \mathrm{g} / \mathrm{mL}$, the viability of the cells decreased at a higher level of glucose induction. Moreover, the viability of the cells of EEDS treatment was significantly different compared to positive control. This result was in line with the previous study which shows that EEDS also has high viability (about $>90 \%$ ) on 3T3-L1 cells (Hidayat et al., 2015). The cell viability decreased as the level of increased-glucose induction. The glucose induction can decrease the cell viability, induced apoptosis, and elevated level of intracellular reactive species in a concentration and time-dependent manner (Hou et al., 2015). The high level of cells viability indicates that the EEDS can protect the cell from damage of glucose induction in the renal cell (Prahastuti et al., 2019a).

In the current study, SV40 MS13 kidney mesangial cells were cultured in a high concentration of glucose which is related to diabetic glomerulosclerosis condition. To study the effect of EEDS on CKD cells model toward, cells viability, FN TGF- $\beta 1$, ROS level which were used as a parameter due to their role in glomerulosclerosis disease. The EEDS $6.25 \mu \mathrm{g} / \mathrm{mL}$ was able to reduce the FN level especially at $5 \mathrm{mM}$ glucose induction as low as $3.72 \pm 0.13 \mathrm{ng} / \mathrm{mL}$. However, the difference between EEDS 3.125 and $6.25 \mu \mathrm{g} / \mathrm{mL}$ treatments was not significant. At this point, it also indicated that higher glucose induction increased FN level. However, the EEDS treatment decreased the FN level significantly compared to positive control both after induced $5 \mathrm{mM}$ and $10 \mathrm{mM}$ of glucose (Figure 1). This result was in line with previous research that jati belanda leaf and mangosteen peel extracts decreased FN level on glucose-induced glomerulus cells (Widowati et al., 2018; Prahastuti et al., 2019a).

The previous study exhibited a significant increase of FN level in a higher level of glucose induction (Nahman et al., 1992). Glucose can increase the FN level which is key protein matrix 


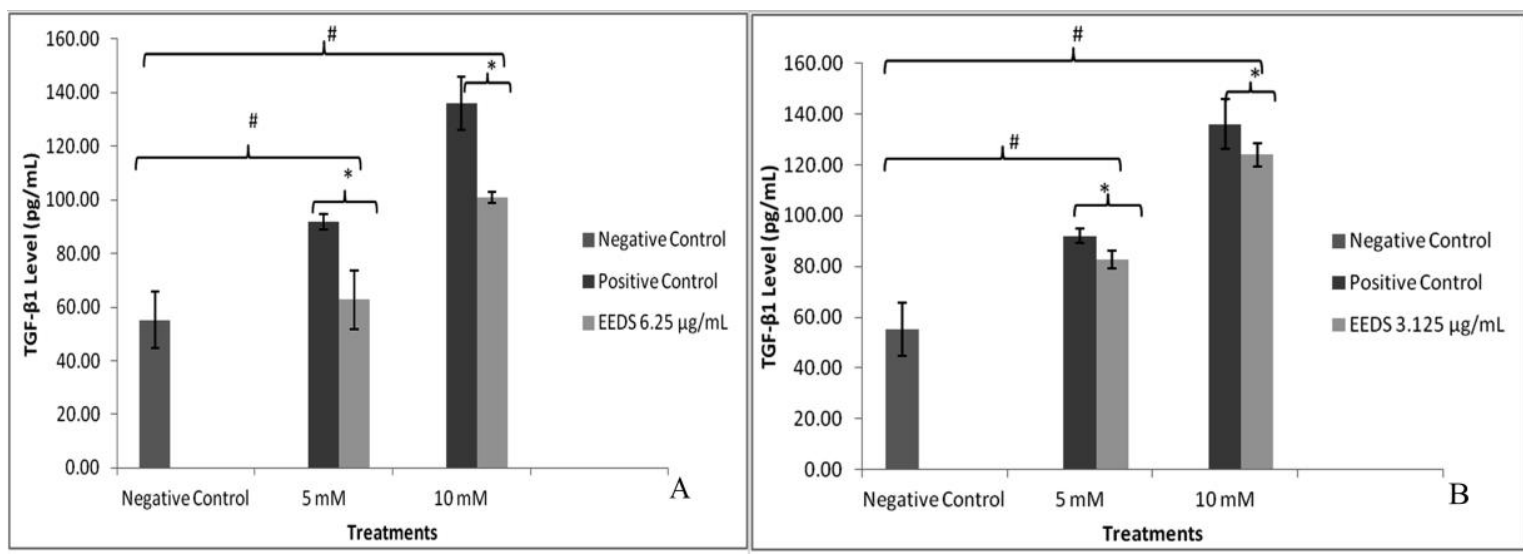

Figure 2. Effect EEDS $(3.125 \mu \mathrm{g} / \mathrm{mL}, 6.25 \mu \mathrm{g} / \mathrm{mL}) \quad$ toward TGF- $\beta 1$ level on $5 \mathrm{mM}$ and $10 \mathrm{mM}$ of glucoseinduced SV 40 MES 13

* The histogram are presented as mean \pm standard deviation of negative control, positive control and EEDS $6.25 \mu \mathrm{g} / \mathrm{mL}(\mathrm{A})$ and EEDS $3.125 \mu \mathrm{g} / \mathrm{mL}(\mathrm{B})$. Asterisk symbols $\left(^{*}\right.$ ) show significant difference between positive control (5 mM, $10 \mathrm{mM}$ glucose induction) and EEDS $6.25 \mu \mathrm{g} / \mathrm{mL}$ treatment, between positive control (5 mM, $10 \mathrm{mM}$ glucose induction) and $3.125 \mu \mathrm{g} / \mathrm{mL}$ treatment on cells $(P<0.05)$ (independent $T$ test). Pound symbol (\#) show significant difference between negative control and positive control (5 mM glucose induction), negative control and positive control $(10 \mathrm{mM}$ glucose induction $)(P<0.05)$ (independent $T$-test).

Table IV. Effect EEDS towad ROS level on glucose-induced mesangial cells

\begin{tabular}{lcc}
\hline Treatment & ROS level (\%) & ROS level (MFI) \\
\hline Positive control (Cell + TBHP) & $82.51 \pm 2.83^{\mathrm{d}}$ & $19.68 \pm 0.67^{\mathrm{e}}$ \\
Negative control (cell + DCFDA) & $6.54 \pm 0.31^{\mathrm{b}}$ & $10.90 \pm 0.49^{\mathrm{bc}}$ \\
Glucose $5 \mathrm{mM}$ & $8.26 \pm 1.48^{\mathrm{b}}$ & $11.40 \pm 0.31^{\mathrm{c}}$ \\
Glucose $10 \mathrm{mM}$ & $50.99 \pm 3.42^{\mathrm{c}}$ & $15.24 \pm 0.56^{\mathrm{d}}$ \\
Glucose $5 \mathrm{mM}+$ EEDS $6.25 \mu \mathrm{g} / \mathrm{mL}$ & $4.58 \pm 1.02^{\mathrm{ab}}$ & $10.06 \pm 0.20^{\mathrm{bc}}$ \\
Glucose $10 \mathrm{mM}+$ EEDS $6.25 \mu \mathrm{g} / \mathrm{mL}$ & $2.26 \pm 0.418^{\mathrm{a}}$ & $10.03 \pm 0.32^{\mathrm{ab}}$ \\
\hline
\end{tabular}

${ }^{*} \mathrm{DCFDA}=2^{\prime}, 7^{\prime}$ dichlorofluorescin diacetate, MFI = mean fluorescence intensity, TBHP = tert-butyl hydroperoxide,

Data are presented as mean \pm standard deviation. Different superscripts in the same column $(\mathrm{a}, \mathrm{ab}, \mathrm{b}, \mathrm{c}, \mathrm{d})$ show significantly differences among treatment in ROS level (\%) and different superscript (a,ab,bc,c,d,e) show significantly differences among treatment in ROS level (MFI) according to Duncan's post hoc test (P $<0.05$ )

accumulation in excess in kidney disease (Wang et al., 2008). The accumulated level of FN on glucose-induced cell can be mediated by oxygenfree radical, therefore the antioxidant can lower the FN accumulation. The result exhibited that EEDS was able to suppress the FN expression in hyperglycemic cell model (Figure 1).

The EEDS $6.25 \mu \mathrm{g} / \mathrm{mL}$ and $3.125 \mu \mathrm{g} / \mathrm{mL}$ decreased TGF $\beta 1$. EEDS $6.25 \mu \mathrm{g} / \mathrm{mL}$ at $5 \mathrm{mM}$ glucose-induced cells showed lowest TGF $\beta 1$ level $(62.73 \pm 10.89 \mathrm{pg} / \mathrm{mL})$, it was the best treatment compared to $10 \mathrm{mM}$ of glucose induction.

TGF- $\beta$ plays a crucial role in mesangial matrix expansion. According to previous study, the injured glomeruli express more TGF- $\beta 1$ mRNA, synthesize more TGF- $\beta 1$ protein, and secrete many fold greater amounts of FN and proteoglycans than normal glomeruli (Okuda et al., 1990). Thus the damage in glomeruli can lead to a renal disease. The excessive amount of TGF- $\beta 1$ due to glucose induction can be suppressed by the the treatment with EEDS. normal glomeruli (Okuda et al., 1990). Thus the damage in glomeruli can lead to a renal disease. The excessive amount of TGF- $\beta 1$ due to glucose induction can be suppressed by the the treatment with EEDS. The EEDS treatment resulted in significant decrease of TGF- $\beta 1$. This result was supported by previous research that jati belanda leaf and mangosteen peel extracts decreased TGF- 


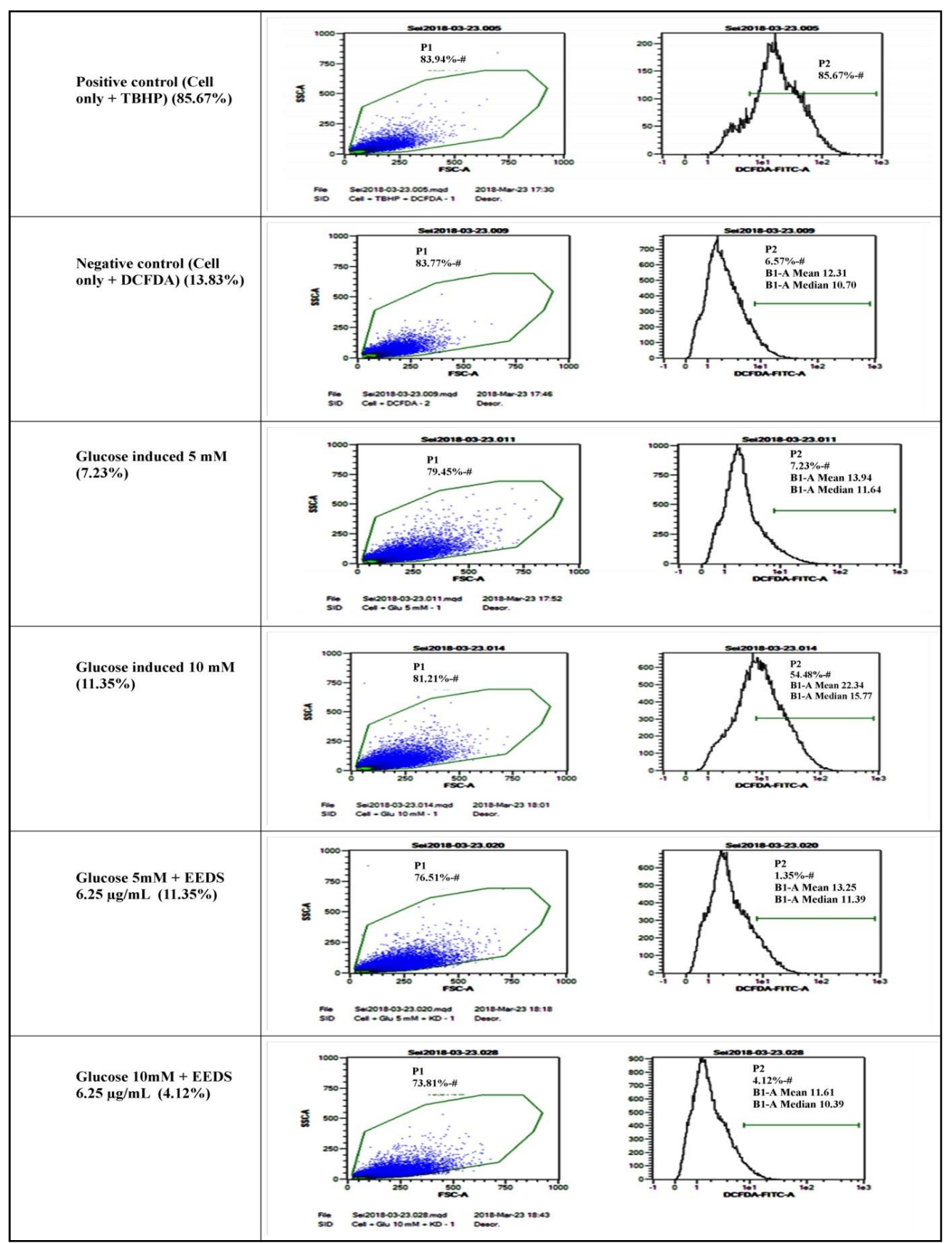

Figure 3. Dot blot of EEDS $6.25 \mu \mathrm{g} / \mathrm{mL}$ on glucose-induced mesangial cell toward ROS level. This figure is the dot blot representative of ROS level in glucose-induced mesangial cells treated with EEDS $6.25 \mu \mathrm{g} / \mathrm{mL}$

${ }^{*}$ EEDS = ethanol extract of detam 1 soybean; TBHP = tert-butyl hyroperoxide; DCFDA = 2',7' dichlorofluorescin diacetate

$\beta 1$ level on glucose-induced glomerulus cells (Widowati et al., 2018; Prahastuti et al., 2019a). The reduction of and TGF- $\beta 1$ levels are associated with antioxidant activity of EEDS. Ethanol extract of soybean is reported to contain phenolic and flavonoid contents which have good potential as an antioxidant (Juan and Chou, 2010; Prahastuti et al., 2019a).

Antioxidant compounds inhibit activation the protein kinase $c$, which induce diabetic nephropathy and also TGF- $\beta 1$ synthesis in the mesangial cell in response to high glucose 
induction. Inhibition of protein kinase c effectively blocks high glucose-, phorbol ester-, and $\mathrm{H}_{2} \mathrm{O}_{2}$ induced TGF- $\beta 1$ and FN synthesis (Ha et al., 1998).

The ROS (\%) level of $10 \mathrm{mM}$ glucoseinduced mesangial cells was higher than $5 \mathrm{mM}$ glucose induction, EEDS treatment $(6.25 \mu \mathrm{g} / \mathrm{mL}$ and $3.125 \mu \mathrm{g} / \mathrm{mL}$ ) decreased ROS level both $5 \mathrm{mM}$ and $10 \mathrm{mM}$ glucose induction was comparable with the negative control. These results indicate that the EEDS treatment can significantly lower the ROS level on CKD cells model (Table 4, Figure 1).

Soybeans showed much higher free-radical scavenging activity, inhibition of lipid peroxidation and ability to chelate metals. Soy isoflavones as antioxidants have been reported to reduce the risk of coronary heart disease. (Ramdath et al., 2017). To inhibit lipid peroxidation, to prevent low density-lipoprotein oxidation and to reduce oxidative DNA damage. Soybean also reported having phenolic compounds which are also a great antioxidant source (Han and Baik, 2008; Prahastuti et al., 2019a). Antioxidants are able to improve cell growth and regenerate a damaged extracellular matrix under high glucose concentration (hyperglycemic) through glycation of proteins (Chen et al., 2012; Kurtz and Oh, 2012; Widowati et al., 2018; Prahastuti et al., 2019a).

Oxidative stress is associated with other disease related to a reduced antioxidant defense which led to a decreased renal function, therefore, it can be said that the antioxidants might exert a key role to protect mesangial cells and might be applied therapeutically as nephroprotective agent as well as prevent renal scarring (Lee and Song, 2009; Tylicki et al., 2003). The presence of antioxidant according to Jha et al. (2016) can ROS into nonreactive oxygen molecules which is harmless to cells (Jha et al., 2016). Also, it obstructs glucose absorption through inhibition of carbohydrate-hydrolyzing enzymes such as $\alpha$ glucosidase and $\alpha$-amylase and down-regulates the TGF- $\beta$ expression and FN level by decreasing NADPH oxidase expression (Widowati et al., 2018; Manaharan et al., 2012; Han et al., 2017; Prahastuti et al., 2019a). Table IV shows that EEDS is capable to lower ROS level mesangial cells treated with 5 and $10 \mathrm{mM}$ glucose compared to the positive control. EEDS is able to reduce ROS level I due to antioxidant activity, therefore it might be considered to be a nephroprotective strategy with further studies.

\section{CONCLUSION}

The authors declare that they have no competing interests.

\section{ACKNOWLEDGMENTS}

We gratefully acknowledge the financial support of Penelitian Terapan Unggulan Perguruan Tinggi 2018 from Directorate General of Higher Education, Ministry of Research, Technology and Higher Education of the Republic of Indonesia. This study supported by Biomolecular and Biomedical Research Center, Aretha Medika Utama, Bandung, West Java, Indonesia. Moreover, we are thankful to Dewani Tediana Yusepany, Dwi Surya Artie, Kamila Yashfa Gunawan, Enden Dea Nataya, Ika Adhani Sholihah, Rr. Anisa Siwi Handayani, Alya Mardhotillah Azizah, Riyani Lestari from Biomolecular and Biomedical Research Center, Aretha Medika Utama, Bandung for their valuable assistance.

\section{REFERENCES}

Chen, C., Cheng, K., Chang, A. Y., Lin, Y., Hseu, Y., Wang, H. 2012. 10-Shogaol, an Antioxidant from Zingiber officinale for Skin Cell Proliferation and Migration Enhancer. Int J Mol Sci 13(2):1762-77.

Dai, M.M., Wu, H., Li, H., Chen, J., Chen, J.Y., Hu, S.L., et al. 2014. Effects And Mechanisms of Geniposide On Rats With Adjuvant Arthritis. Int Immuno Pharmacol. 20(1): 46-53.

Dounousi, E., Papavasiliou, E., Makedou, A., Loannou, K., Katopodis, K.P., Tselepis, A., et al. 2006. Oxidative Stress Is Progressively Enhanced With Advancing Stages of CKD. Am J Kidney Dis 48:752- 760.

Garcı'a-Sa'nchez, O., Lo'pez-Herna'ndez, F.J., Lo'pez-Novoa, J.M. 2010. An Integrative View On The Role of TGF-B In The Progressive Tubular Deletion Associated With Chronic Kidney Disease. Kidney Int 77: 950-955.

Gemede, H. F., Ratta, N. 2014. Antinutritional Factors In Plant Foods: Potential Health Benefits And Adverse Effects. Int J Nutr Food Sci 3(4): 284-289.

Gilmore, B. L., Liang, Y., Winton, C. E., Patel, K., Karageorge, V., Varano, A. C., et al. 2017. Molecular Analysis Of BRCA1 In Human Breast Cancer Cells Under Oxidative Stress. Sci Rep 7(1): 43435 
Ha, H., Yu, M. R., Kim, K. H. 1998. Melatonin and Taurine Reduce Early Glomerulopathy in Diabetic Rats. Free Radic Biol Med 26(7):944-950.

Han, H., Baik, B. K. 2008. Antioxidant Activity and Phenolic Content of Lentils (Lens culinaris), Chickpeas (Cicer arietinum L.), Peas (Pisum sativum L.) and Soybeans (Glycine max), and Their Quantitative Changes during Processing. Int J Food Sci Technol 43:19711978

Han, H., Cao, A., Wang, L., Guo, H., Zang, Y., Li, Z., et al. 2017. Decoction Ameliorates Streptozotocin-Induced Rat Diabetic Nephropathy Through Antioxidant And Regulation of The TGF-B /MAPK /PPAR- $\Gamma$ Signaling. Cell Physiol Biochem 42(5):193444.

Hayata, M., Kakizoe, Y., Uchimura, K., Morinaga, J., Yamazoe, R., Mizumoto, T., et al. 2012. Effect Of A Serine Protease Inhibitor On The Progression Of Chronic Renal Failure. Am J Physiol Renal Physiol 303: F1126-F1135.

Hidayat, M., Prahastuti, S., Fauziah, N., Maesaroh, M., Balqis, B., Widowati, W. 2016. Modulation of Adipogenesis-Related Gene Expression by Ethanol Extracts of Detam 1 Soybean and Jati Belanda Leaf in 3T3-L1 Cells. Bangladesh J Pharmacol 11: 697-702.

Hidayat, M., Soeng, S., Prahastuti, S., Erawijantari, P. P., Widowati, W. 2015. Inhibitory Potential of Ethanol Extract of Detam 1 Soybean (Glycine max) Seed and Jati Belanda (Guazuma ulmifolia) Leaves on Adipogenesis and Obesity Models in 3T3-L1 Cell Line. JSRR 6(4): 304-12.

Hou, Q., Lei, M., Hu, K., Wang, M. 2015. The Effects of High Glucose Levels on Reactive Oxygen Species-Induced Apoptosis and Involved Signaling in Human Endothelial Cells. Cardiovasc Toxicol 15(2): 140-6.

Jha, C. J., Banal, C., Chow, B. S. M., Cooper, M. E., Dahm, K. J. 2016. Diabetes and Kidney Disease: Role of Oxidative Stress. Antioxid Redox Signal 25(12):657-84.

Juan, M. Y., Chou, C. C. 2010. Enhancement of Antioxidant Activity,Total Phenolic and Flavonoid Content of Black Soybeans by Solid State Fermentation with Bacillus subtilis BCRC14715. Food Microbiol 27(2010):586-591.

Kurtz, A., Oh, S. 2012. Age Relted Changes of The Extracelullar Matrix and Stem Cell Maintenance. Prev Med 54(2012):S50-S56.

Lee, H. S., Song, C. Y. 2009. Oxidized Low-Density Lipoprotein and Oxidative Stress In The
Development Of Glomerulosclerosis. Am J Nephrol 29(1):62-70.

Loeffler, I., Wolf, G. 2013. Transforming Growth Factor- $\beta$ and The Progression of Renal Disease. Nephrol Dial Transplant 29(1):3745.

Manaharan, T., Palanisamy, U. D., Ming, C. H. 2012. Tropical Plant Extract as Potential Antihyperglycemic Agents. Molecules 17(5):5915-23.

Miller, C.G., Pozzi, A., Zent, R., Schwarzbauer, J.E. 2014. Effects of High Glucose on Integrin Activity and Fibronectin Matrix Assembly By Mesangial Cells. Mol Biol Cell 25(16): 2342-2350.

Nahman, N. S., Leonhart, K. L., Cosio, F. G., Hebert, C. L. 1992. Effects of High Glucose on Cellular Proliferation and Fibronectin Production By Cultured Human Mesangial Cells. Kidney Int 41(2): 396-402.

Okuda, S., Languino, L. R., Ruoslahti, E., Border, W. A. 1990. Elevated Expression of Transforming Growth Factor-Beta and Proteoglycan Production in Experimental Glomerulonephritis. Possible Role In Expansion of The Mesangial Extracellular Matrix. J Clin Invest 86: 453-462

Pankov, R., Yamada, K. M. 2004. Non-radioactive Quantification of Fibronectin Matrix Assembly. Curr Protoc Cell Biol. Chapter 10: 10-13.

Peng, H., Li, W., Li, H., Deng, Z., Zhang, B. 2017. Extractable and Non-Extractable Bound Phenolic Compositions and Their Antioxidant Properties In Seed Coat And Cotyledon of Black Soybean (Glycine max (L.) merr). J Funct Food 32: 296-312.

Prahastuti, S., Hidayat, M., Hasianna,S. T., Widowati, W., Amalia, A., Yusepany,D.T., Rizal, R. Kusuma, H.S.W. 2019a. Antioxidant potential ethanolic extract of Glycine max (1.) Merr. Var. Detam and daidzein. J Phys Conf Ser 1374: 012020

Prahastuti, S., Hidayat, M., Hasianna, S. T., Widowati, W., Amalia, A., Qodariah, R.L., Rizal, R., Kusuma, H.S.W. Khoiriyah, Z. 2019b. Ethanol Extract of Jati Belanda (Guazuma ulmifolia L.) as Therapy for Chronic Kidney Disease in In Vitro Model. J Reports Pharmaceutic Sci 8(2):229-235

Ramdath, D. D., Padhi, E. M. T., Sarfaraz, S., Renwick, S., Duncan, A. M. 2017. Beyond the Cholesterol-Lowering Effect of Soy Protein: A Review of the Effects of Dietary Soy and Its Constituents on Risk Factors for Cardiovascular Disease. Nutrients 9:324 
Ranich, T., Bhathena, S.J., Velasquez, M.T. 2001. Protective Effects of Dietary Phytoestrogens in Chronic Renal Disease. J Ren Nutr. 11(4): 183-193.

Tylicki, L., Rutkowski, B., Hörl, W. H. 2003. Antioxidants: A Possible Role in Kidney Protection. Kidney Blood Press Res 26: 30314.

Uchiyama-Tanaka, Y., Matsubara, H., Mori, Y., Kosaki, A., Kishimoto, N., Amano, K., et al. 2002. Involvement of HB-EGF and EGF Receptor Transactivation in TGF Mediated Fibronectin Expression in Mesangial Cells. Kidney Int 62: 799-808.

Widowati, W., Darsono, L., Suherman, J., Fauziah, N., Maesaroh, M., Erawijantari PP. 2016. Anti-Inflammatory Effect of Mangosteen (Garcinia mangostana L.) Peel Extract and Its Compounds In LPS-Induced RAW 264.7 Cells. Nat Prod Sci 22(3): 147-153.
Widowati, W., Rani, A.P., Hamzah, R. A., Arumwardana S, Afifah E, Kusuma HSW, et al. 2017. Antioxidant and Antiaging Assays of Hibiscus sabdariffa Extract and Its Compounds. Nat Prod Sci 23(3): 192-200.

Widowati, W., Laksmitawati, D. R., Wargasetia, T. L., Afifah, E., Amalia, A., Arinta, Y., et al. 2018. Mangosteen Peel Extract (Garcinia mangostana L.) as Protection Agent In Glucose-Induced Mesangial Cell as In Vitro Model Diabetic Glomerulosclerosis. Iran J Basic Med Sci 21(9): 972-977.

Yu, T., Jhun, B. S., Yoon, Y. 2011. High-glucose Stimulation Increases Reactive Oxygen Species Production Through The Calcium and Mitogen-Activated Protein KinaseMediated Activation of Mitochondrial Fission. Antioxid Redox Sign 14(3):425-37. 